\title{
LEARNING PROBLEMS OF ISLAMIC EDUCATION AT SMA LB OF REJANG LEBONG
}

\author{
Idi Warsah \\ Institut Agama Islam Negeri Curup, Bengkulu \\ E-mail: idiwarsah@gmail.com \\ DOI: https://doi.org/10.29313/tjpi.v9i1.6540 \\ Submitted: June 03th, 2020. Approved: June 29th, 2020. Published: June 29th, 2020
}

\begin{abstract}
Children with disabilities have the same rights in terms of education, both general and Islamic religious education. The present study aimed to investigate the main learning problems of Islamic education subject for students with disabilities. This study was conducted at SMA LB of Rejang Lebong. This study applied a descriptive qualitative approach. The Islamic education teacher at this school was engaged as the subject. The data were collected using interview and observation techniques. The data were further analyzed using an interactive model whose elements included data collection, data condensation, data display, and conclusion drawing. This study revealed that there were three main problems in Islamic education learning found at SMA LB of Rejang Lebong. These problems included a lack of teaching staffs (teachers), lack of parental supports, and lack of training provisions for the Islamic education teacher in an effort to help the teacher provide ideal teaching and learning processes for students with special needs. The findings of this study call for immediate solutions to be offered, especially by the school per se and Rejang Lebong's local government.
\end{abstract}

Keywords: Problems; Islamic education learning; Students with disabilities

\begin{abstract}
Abstrak
Anak penyandang disabilitas memiliki bak yang sama dalam hal pendidikan, baik pendidikan umum maupun pendidikan agama Islam. Penelitian ini bertujuan untuk mengetabui permasalaban pokok, pembelajaran pendidikan Islam bagi siswa disabilitas. Penelitian ini dilakukan di SMA LB Rejang Lebong. Penelitian ini menggunakan pendekatan kualitatif deskriptif. Guru mate pelajaran pendidikan agama Islam di sekolah ini dilibatkan sebagai subjek. penelitian. Pengumpulan data dilakukan dengan menggunakan teknik wawancara dan observasi. Selanjutnya, analisis data menggunakan model interaktif yang elemen-elemennya meliputi pengumpulan data, kondensasi data, penyajian data, dan penarikan kesimpulan. Hasil penelitian ini mengungkapkan bahwa terdapat tiga masalab pokok dalam pembelajaran pendidikan agama Islam di SMA LB Rejang Lebong. Permasalaban tersebut antara lain adalah kurangnya tenaga pengajar (guru), kurangnya dukungan orang tua, dan kurangnya bekal pelatihan bagi guru pendidikan Islam dalam upaya membantu guru untuk memberikan proses belajar mengajar yang ideal bagi siswa berkebutuhan kbusus. Temuan studi ini mengundang agar segea ada solusi yang ditawarkan terutama dari sekolah itu sendiri dan pemerintah daerah Rejang Lebong.
\end{abstract}

Kata Kunci: Masalah, Pembelajaran pendidikan agama Islam; Siswa disabilitas 


\section{INTRODUCTION}

In Law Number 8 of 2016 concerning people with disabilities, article 1 , point 1 , it is explained that people with disabilities are everyone who experiences physical, intellectual, mental, and sensoric limitations for a long time, wherein they experience obstacles and difficulties to participate fully and effectively in social engagement. In a more general perspective, people with disabilities are usually associated with those having mental and physical limitations. Some people with disabilities have mental disabilities that might affect their ability to make decisions about a problem, or in some way their conditions tend to hinder them from perceiving and processing information. On the other hand, some people with disabilities also experience constraints in the aspect of physical problems. In terms of education, the aforementioned two major aspects, mental and physical constraints, require special guidance from teachers, parents, and the surrounding environment (Bigby, 2016; Cebulla \& Zhu, 2015; Curryer, Stancliffe, \& Dew, 2015; Frielink, Schuengel, \& Embregts, 2018; Maggio, Shogren, Wehmeyer, \& Nota, 2019; Retnaningsih \& Dini, 2016; Rillotta \& Alexander, 2020; Sexton, Donovan, Mulryan, \& Mccallion, 2016; Yuliana, 2019).

Children with physical disabilities are much less physically active than those without disabilities. The physical activities they do also tend to be more limited (Gibbons \& Gibbons, 2016). However, in an ideal way, even though they have physical limitations, they still have the right to receive education in terms of both general lessons and Islamic education lesson. The foregoing context is in line with the theory that underlies the essence of inclusion in education, in which all human beings, without exception for those with disabilities, have equal rights of education (Engelbrecht, Nel, Smit, \&
Deventer, 2015). Equality of rights in receiving education is also often echoed by the theoretical viewpoint of critical pedagogy which emphasizes the essence that people who have different social affiliations and innate affiliations (such as mental and physical differences) still have the right to get an equal education (GilGlazer, 2017; Pennycook, 2017; Pittard, 2015; Schwimmer, 2019).

Regarding Islamic education for children with special needs, Rahmawati (2018) scrutinized the learning processes of Islamic education for children with special needs at an elementary school in Jepara. Her study revealed that the implementation of Islamic education learning at this school is not much different from other regular schools. The materials taught are the same, while the methods used are adjusted to the materials being taught. In certain materials, children with special needs respond quickly to materials a parody method is applied. Educators are highly required to be creative in organizing the learning processes because in one class, there are students from various background conditions. Therefore, to support learning that is conducive to certain conditions, educators at this elementary school divides split students into two groups, namely: a large group and a small group to optimize the learning processes of Islamic education.

Children with special needs require special learning concepts (Bij, Geijsel, Garst, \& Dam, 2016; Hannås \& Hanssen, 2016; Ratner, 2016). The same thing is also needed by students at SMA LB of Rejang Lebong that require their own learning concepts which are different from other children without disabilities. Integrated learning is needed in order to achieve learning targets, namely being independent learners. One subject that receives attention is Islamic education subject. Ideally, the goal of this subject is to shape children's personality so that it 
remains in accordance with Islamic values, and children can be responsible for their religious life so that they become strong and morally good according to the teachings of Islam.

Based on the results of a study conducted by Sukijan (2018) on Islamic education for mentally retarded children, children with mental retardation have the right to get proper Islamic education. In this regard, Muslim children are provided with Islamic education services to properly instill Islamic aqidah. The implementation of Islamic education can have positive implications for children with mental retardation. They can better understand the theory and practice of Islam well. With the knowledge they have, they will realize that Allah is almighty over his creations, so that mentally retarded children do not drag on lamenting their lack of conditions. They can be very aware of situations and can provide mental stability.

Teachers have a very important role in the world of education. Therefore, teachers who are competent in both general and religious sciences are needed (Warsah, Aisa, \& Sendi, 2020; Zubaidillah \& Nuruddaroini, 2019). Teachers must have a good personality that can be a role model for students (Warsah \& Uyun, 2019), and they must have a patient disposition in guiding students especially those with disabilities or those with special needs (Keane, Heinz, \& Eaton, 2017; Rillotta \& Alexander, 2020; Ware \& Schuelka, 2019). Based on the results of a study undertaken by Sabaria (2019) regarding the strategies of Islamic education teachers in improving the psychomotor abilities of autistic students, first, the psychomotor-related competence of autistic students tends to imitate others. They can practice ablution and prayer through the examples and instructions given by the teacher. Second, the strategies of Islamic education teachers in improving the psychomotor- related competence of autistic students on the ability to practice ablution and prayer extend to choosing the right method such as the method of demonstration, using media in the form of pictures, and heightening patience in teaching the students in a way that never get bored of repeating the movements of ablution and prayer in front of students.

Regarding SMA LB of Rejang Lebong which is the field of this study, the curriculum used at SMA LB of Rejang Lebong is the K-13 curriculum by combining various fun learning methods such as learning while playing and inviting children to learn in a relaxed manner that is not overwhelmed by materials leading them to being bored quickly when studying. Based on Muchtar's (2018) study, there are five concepts of Islamic education for children with special needs, namely: Islamic education aims to make students independent and able to lead themselves and have Islamic character; the Islamic education curriculum used has the same materials between ones in regular classes and those for students with special needs, but what makes a difference is the adjustment to the students' abilities in delivering the materials; there are three methods of Islamic education used, namely classical methods, habituation, and role models; the process of evaluating Islamic education that is implemented is adjusted to the school curriculum; and Islamic education tools and media are prepared according to the needs of each student.

In dealing with children with special needs, care givers including parents and teachers need knowledge of these children and skills in caring for and serving them (Keane et al., 2017; Rillotta \& Alexander, 2020; Ware \& Schuelka, 2019). Simply speaking, caregivers, parents, and teachers need to know some positive psychologybased knowledge (Warsah, 2020a) so that they can appropriately guide children with special needs. Children with special needs 
need encouragement, guidance, and direct practice gradually. The potential of children with special needs will grow along with the success of the companion's role in understanding and cultivating their potential. However, in terms of Islamic education, there are of course various problems faced by both Islamic education teachers, students, and their parents, whereby these problems include various elements covering the aspects of whilelearning and post-learning. In addition, the Islamic education subject requires students to be able to not only understand theories but also related practices in everyday life.

Based on the results of a study undertaken by Handayani and Makarim (2018), the learning processes of Islamic education for children with special needs include the following details: 1) The scopes of materials for Islamic religious education cover the Qur'an, aqidah, morals, figh, and the history of Islamic culture. 2) The methods used during learning include lecturing method, discussion method, demonstration method, practice-based method, and question and answer method. 3) The evaluation of Islamic education learning processes is carried out by making a grid of questions that are in accordance with the competency standards of learning indicators, making question items for each indicator, processing the data of test results, analyzing test results, and making improvements and enrichment. 4) Inhibiting factors for Islamic education teachers in carrying out the learning processes consist of internal factors and external factors. 5) Supporting factors in learning Islamic education include students' learning experiences and parents' attention to students at home. 6) The implementation of Islamic education learning processes includes making a lesson plan and carrying out learning activities resting upon the lesson plan.
In an effort to engage students with disabilities into learning, students' level of trust needs to be built so that they do not feel isolated. Teachers must help them explore the potential that exists within them so that they can work to develop their talents like children in general. Based on the results of a study conducted by Marlina (2015) on the rational emotive behavior therapy model to increase the confidence of blind children, this model can increase blind children's confidence. It is evident that after learning with this model, children with visual impairments have the courage to gather with their friends and dare to say hello and start conversations. Furthermore, the children eventually have a sort of initiative and a sense of responsibility for themselves. This is evidenced by their consistency in carrying out household chores such as washing clothes, making beds, and tidying up clothes as well as items. Such activities are carried out by the subjects without any order or command from the dorm supervisor.

Based on the above overview, this study is conducted with the purpose of exploring the problems of Islamic education learning at SMA LB Rejang Lebong.

\section{RESEARCH METHOD}

This study was conducted by applying a qualitative research approach (Creswell, 2007; Gall, Gall, \& Borg, 2003). This approach was used because the data needed by the researcher were only in the form of information, explanations, and oral information (Ary, Jacobs, Sorensen, Walker, \& Razavieh, 2010). In this study, the researcher provided a set of explanations with respect to the learning problems of Islamic education for students with disabilities. This study was conducted at SMA LB of Rejang Lebong. The data were obtained from the Islamic education teacher at SMA LB of Rejang 
Lebong selected according to the criteria that the researcher wanted to seek based upon the context of the present study. The Islamic education teacher was engaged as the participant using a purposive sampling technique.

In this study, the data were garnered using two techniques namely interviews and observation. Interviews were conducted to trace the truth and obtain accurate and precise information vis-a-vis the learning problems of Islamic education for students with disabilities at SMA LB of Rejang Lebong. Interviews were conducted openly to find out information about problems that existed in the field that the researcher was studying. Observations were also carried out directly during the learning processes of Islamic education held by the teacher at SMA LB of Rejang Lebong. The data obtained from observations were further compared with those solicited from interviews. The data comparison as such indicated a way of data triangulation which was functioned as data verification so that the plausible bias of data could be avoided or reduced. After all data were collected, the data were subsequently analyzed using an interactive model as suggested by Miles, Huberman, and Saldana (2014). This interactive model contained several important elements, namely data collection, data condensation, data display, and drawing a conclusion. Data collection was carried out as explained above by means of interviews and observations. Data condensation was done by means of grouping the data pursuant to some meaningful themes. Data display was undertaken by presenting the data based on their coded themes in a way that gave detailed explanations and discussions. Lastly, the conclusion or summary of all of the data was drawn in a proper way.

\section{FINDINGS AND DISCUSSION}

From the results of observations at SMA LB of Rejang Lebong, there were 4 groups of children with disabilities, namely autism, mental retardation, visual impairment, and hearing impairment. Appertaining to the learning processes of Islamic education which took place, the observation data showed that the curriculum used at SMA LB Rejang Lebong applied K-13. Likewise learning processes in general, what the teacher did before teaching was usually to prepare learning methods and media as well as to take care of students' conditions before they started learning. In so doing, the learning atmosphere could expectedly be pleasant so that the materials delivered could easily be acquired by disabled students. The implementation of Islamic education learning at SMA LB of Rejang Lebong was still guided by the governmental curriculum wherein in practice the application subsumed some methods such as lecturing, demonstration, and question-and-answer methods pursuant to the syllabus and lesson plan. The teacher used Islamic education learning methods based on the characteristics of disabled students by integrating the processes of habituation and creativity as an educational pattern. This pattern is expected to produce output that led children with special needs to understanding and deeply believe in Allah SW'T, learn the Qur'an, perform worship (for instance, prayer and fasting), and behave in a commendable manner.

However, the processes of Islamic education learning carried out at SMA LB were not free from problems. Based on the results of this study, there are several themes that can be mapped regarding problems in learning the Islamic education subject at SMA LB of Rejang Lebong. These themes along with the related data presentation and discussion are presented in the following elaborations.

\section{Lack of Teachers}


Based on observational data, the number of teachers for Islamic education subject at SMA LB of Rejang Lebong was categorized as lacking. There was only one Islamic education teacher with a teaching decree specified to teach students at elementary school level. However, at SMA LB of Rejang Lebong, she had to teach senior high school students with disabilities. In addition, the teacher had to teach students with four categories of disabilities, namely hearing impairment, mental retardation, blindness, and autism. The students' characteristics were very different, and such a condition would certainly lead the teacher to face many of great challenges in her effort to provide students with adequate learning as desirable. In addition, each characteristic of children with disabilities also required a special way of teaching Islamic education subject. This information is strengthened by interview data provided by the Islamic education teacher as follows:

"I often have problems in dealing with different students' characteristics. Students who are affiliated with hearing impairment, mental retardation, blindness, and autism need different teaching approaches. On the one hand, I do not have sufficiently in-depth knowledge pertinent to psychological and social characteristics of their behavior. For example, when I teach Islamic education materials to autistic students, with my little knowledge of psychology about autistic children, I often get confused about how to persuade them when their moods to study seem low. In my opinion, an Islamic education teacher who masters insights with regard to positive psychology is needed by this school."

The interview data above show that an inadequate number of Islamic education teachers having special competences in dealing with students with disabilities became a problem in promoting the success of Islamic education learning processes. Ideally, children with disabled characteristics get treatments of Islamic education which are mediated by the teacher who are competent and skillful at pedagogical knowledge vis-a-vis a variety of disabled students' characteristics. Such teacher's competence and skill become one of the main factors supporting the success of Islamic education learning. In addition, the competence of Islamic education teacher also includes the mastery of Islamic concept internalization (Isti, Faiz, \& Widodo, 2019).

\section{Lack of Parental Supports}

The observation data also show that there were less-maximal supports from parents to encourage students with disabilities at SMA LB of Rejang Lebong to sustainably be enthusiastic about learning. It could be seen that there were merely less than $50 \%$ of the students that were escorted and picked up by their parents directly. In the meantime, they were children with special needs who must be taken seriously, including their small things such as school shuttle needs. At glance, the foregoing seemed like a small problem, but this condition had an impact on students' moods to study. This is confirmed by the following interview data with the Islamic education teacher:

"Of all students with disabilities that I teach, maybe there are only $40 \%$ of them who are always escorted and picked up by their parents. They are blind and autistic students. However, for other students, their parents did not always pick them up and drop them off. Often times, their caregivers are those who drop them and pick them up, but not their parents who do such a thing directly. With this condition, I very 
often find students who look sad and have no passion for learning. As a consequence, their learning processes cannot run in an ideal way".

The interview data above show that parents' serious attention to children with disabilities would greatly contribute to the successful continuity of Islamic education learning processes at SMA LB of Rejang Lebong. The opposite would happen if the students did to get serious attention. Furthermore, in the interview, the Islamic education teacher also said that parents' attention to the children with disabilities at home was also lacking. Ideally, parents should always work together with teachers. For example, teachers provide materials to students at school. Parents assist students in repeating their lessons at home so that students with disabilities are able to practice Islamic lessons that they learn at SMA LB of Rejang Lebong in their daily lives. For instance, such a material of ablution as students learn at school, the parents should also guide their children to practice a proper way of wudhu at any time they would like to take a pray. Thus, even though they have various limitations, students can still perform ablution properly because they are accustomed to being guided both by teachers at school and by parents at home.

\section{Lack of Training for Islamic Education Teacher}

The observational data also show that special training for the Islamic education teacher in dealing with children with disabilities was lacking. The competence of Islamic education teacher at SMA LB of Rejang Lebong, that was basically merely resting upon the decree to teach students at elementary school level, required the provision of special training from schools. This is as stated by the
Islamic education teacher in the interview as displayed in the following transcript:

"I admit that I really need various kinds of training so that I can provide the best learning for children with special needs at SMA $\mathrm{LB}$ of Rejang Lebong. This is because my teaching decree was to teach at Elementary School, while the students I teach are high school students. There are many pedagogical competences for teaching students with disabilities at the high school level that I have not mastered. Second, I need special training so that I can have a deeper dialogue with the students in a psychological aspect”.

The data portrayed in the above interview transcript show that in order to prepare a competent Islamic education teacher in teaching children with disabilities, sufficient training was needed in both pedagogical and psychological fields. According to Fikri (2017), one of the training provisions in the field of pedagogy can be oriented towards teaching methods. Referring to previous research, there are several variations of effective teaching methods that can be trained for Islamic education teachers who teach students with disabilities. Some of the methods are lecturing, discussion, demonstration, exercises, and questionand-answer methods (Rusdiyanto, 2018). At first glance, the names of these methods are the same as general variants of teaching methods, but their implementation in the context of teaching children with special needs need to be executed differently according to students' needs (Aisah \& Santosa, 2019; Fadlilah, 2017). In teaching students with disabilities, according to Susiana (2017), every child with disability has a very different behavioral characteristic. The abilities of students in the classroom are not the same. This case will naturally result 
in obstacles for educators in delivering lessons. If educators only pay attention to students who easily grasp information, then the class situation will not be harmonious, and in turn it will lead to jealousy in the hearts of low-intelligent students because they feel unnoticed. If the foregoing case happens, the instructional goals will not be wellachieved.

As a further discussion, this study reveals three main problems of Islamic education learning found at SMA LB of Rejang Lebong. These problems include a lack of teaching staff, lack of parental support, and lack of training provisions for Islamic education teachers in teaching children with special needs. The findings of this study call for an immediate solution to be offered, especially from the school and Rejang Lebong's local government. Learning from previous studies, there are several studies that have recommended some solutions to various problems of Islamic education learning for children with special needs. For example, the findings of a study conducted by Jannah (2017) suggested that the teacher applies a habituation method in educating children with special needs in teaching Islamic education subject, for example getting students to read the Qur'an by means of executing the Qur'an reading and writing programs. Furthermore, the teacher must try to create a relaxed and fun learning atmosphere for students (Warsah, 2020b). Related to the problem of the lack of interest and motivation of children with disabilities in learning Islamic education subject, the ideal effort given by the teacher is to form a good, interesting and fun learning climate. This effort can be carried out by the teacher using learning methods and media that are not monotonous, implementing learning by practice in the field, giving students the opportunity to practice the materials being taught, providing students with interesting information and materials, and choosing material explanations that have direct association with students in everyday life (Jannah, 2017).

Learning from Amma's (2018) research which provides solutions to the problems of an Islamic education teacher in carrying out teaching and learning processes for students with disabilities, ideally the school managers contribute to helping the teacher by activating discussions on Islamic religious education, implementing teacher's sharing programs, providing learning infrastructure for Islamic education optimally, facilitating teachers to attend trainings according to the competencies they want to develop, and motivating teachers by the school leader. To some extent, this is also in line with Supandi (2018) who explained that school managers should ideally try to foster the teacher who teaches students with disabilities to be more creative through religious discussions, providing the necessary infrastructure, and involving the teacher in related-training programs or seminars according to the competence expected. Furthermore, in creating a good environment, efforts could be made to hold religious programs such as praying dzuhur together, memorizing short verses of Qur'an together, and other congregational Islamic religious activities. Such Islamic practice-based programs are very useful to gradually establish a good habit of students with disabilities to practice worship. In short, the present study strongly recommends that SMA LB of Rejang Lebong and the local government work together to help the Islamic education teacher by providing adequate school facilities and lots of training facilities so that the teacher has adequate competences in dealing with students with special needs. Thus, learning problems of Islamic education at SMA LB of Rejang Lebong can be minimized and even resolved.

\section{CONCLUSION}


Idi Warsah / Ta'dib: Jurnal Pendidikan Islam, Vol. 9 No. 1 (2020)

ISSN 1411-8173 | E-ISSN 2528-5092

https://ejournal.unisba.ac.id/index.php/tadib/article/view/6540

This study has found three main problems faced in the learning of Islamic education subject at SMA LB of Rejang Lebong. These problems include a lack of teaching staffs (teachers), lack of parental supports, and lack of training provisions for the Islamic education teacher in teaching children with special needs. The findings of this study call for immediate solutions to be offered, especially by the school per se and Rejang Lebong's local government. It is highly recommended that the management of SMA LB of Rejang Lebong and the local government work together to help the Islamic education teachers by providing adequate school facilities and lots of training facilities so that the teacher has adequate competences in dealing with students with special needs. Thus, the learning problems of Islamic education subject at SMA LB of Rejang Lebong can be minimized and even resolved.

\section{REFERENCES}

Aisah, A., \& Santosa, D. (2019). Peningkatan kapasitas guru PAI melalui pelatihan modifikasi kurikulum menggunakan differentiated instruction untuk siswa disabilitas intelektual. Islamadina: Jurnal Pemikiran Islam, 19-35.

Amma, T. (2018). Problematika proses pembelajaran pendidikan agama Islam. Al-I'tibar: Jurnal Pendidikan Islam, 5(2), 70-78.

Ary, D., Jacobs, L. C., Sorensen, C. K., Walker, D. A., \& Razavieh, A. (2010). Introduction to research in education. Measurement (8th ed., Vol. 4). USA: Wadsworth, Cengage Learning. https://doi.org/10.1017/CBO97811 07415324.004

Bigby, C. (2016). Is the national disability insurance scheme taking account of people with intellectual disabilities? Research and Practice in Intellectual and Developmental Disabilities, 1(2), 93-97. https://doi.org/10.1080/23297018.2 014.974484
Bij, T. Van Der, Geijsel, F. P., Garst, G. J. A., \& Dam, G. T. M. Ten. (2016). Modelling inclusive special needs education: insights from Dutch secondary schools. European Journal of Special Needs Education, 31(2), 220235.

https:/ /doi.org/10.1080/08856257.2 016.1141509

Cebulla, A., \& Zhu, R. (2015). Disability, and social and economic inclusion: who is in and out of the Australian National Disability Insurance Scheme? Scandinavian Journal of Disability Research, 1-13. https://doi.org/10.1080/15017419.2 015.1064026

Creswell, J. W. (2007). Qualitative inquiry \& research design: Choosing among five approaches (2nd ed.). USA: SAGE publications, Inc.

Curryer, B., Stancliffe, R. J., \& Dew, A. (2015). Self-determination: Adults with intellectual disability and their family. Journal of Intellectual and Developmental Disability, 40(4), 394-399. https://doi.org/10.3109/13668250.2 015.1029883

Engelbrecht, P., Nel, M., Smit, S., \& Deventer, M. Van. (2015). The Idealism of Education Policies and the Realities in Schools: The Implementation of Inclusive Education in South Africa. International Journal of Inclusive Education, 1-16. https:/ /doi.org/10.1080/13603116.2 015.1095250

Fadlilah, S. (2017). Strategi pembelajaran PAI bagi peserta didik tunagrabita di SD Suryo Bimo Kresno Semarang. UIN Walisongo.

Fikri, M. T. (2017). Penguatan nilai agama pada anak berkebutuhan khusus (tunanetra) melalui seni musik. $A l$ Ulya, 2(2).

Frielink, N., Schuengel, C., \& Embregts, P. J. C. M. (2018). Autonomy support, need satisfaction, and motivation for support among adults with intellectual disability: Testing a selfdetermination theory model. American Journal on Intellectual and Developmental Disabilities, 123(1), 33-49. https://doi.org/10.1352/1944-7558- 
Idi Warsah / Ta'dib: Jurnal Pendidikan Islam, Vol. 9 No. 1 (2020)

ISSN 1411-8173 | E-ISSN 2528-5092

https://ejournal.unisba.ac.id/index.php/tadib/article/view/6540

123.1.33

Gall, M. D., Gall, J. P., \& Borg, W. R. (2003). Educational research: An introduction (7th ed.). USA: Allyn and Bacon.

Gibbons, H. M., \& Gibbons, C. M. (2016). Siblings with disabilities: a duoethnography on the intersections between a sibling relationship and disability. Disability \& Society, 31(6), 820-837.

https://doi.org/10.1080/09687599.2 016.1203291

Gil-Glazer, Y. (2017). Visual culture and critical pedagogy: from theory to practice. Critical Studies in Education, 120.

https:// doi.org/10.1080/17508487.2 017.1292298

Handayani, S., \& Makarim, C. (2018). Proses pembelajaran pendidikan agama Islam bagi anak berkebutuhan khusus di SDN Perwira-Kota Bogor. Attadib: Journal of Elementary Education, 2(1), 12-26.

Hannås, B. M., \& Hanssen, N. B. (2016). Special needs education in light of the inclusion principle: an exploratory study of special needs education practice in Belarusian and Norwegian preschools. European Journal of Special Needs Education, 1-15. https://doi.org/10.1080/08856257.2 016.1194576

Isti, Faiz, S., \& Widodo, H. (2019). Membangun character building bagi anak difabel dalam pembelajaran pendidikan agama Islam. Al-Hikmab: Jurnal Agama Dan Ilmu Pengetahuan, 16(2), 98-107.

Jannah, R. (2017). Upaya meningkatkan keberhasilan pembelajaran pendidikan agama Islam. Madrosatuna: Journal of Islamic Elementary School, 1(1), 47-58.

Keane, E., Heinz, M., \& Eaton, P. (2017). Fit (ness) to teach ?: disability and initial teacher education in the republic of Ireland. International Journal of Inclusive Education, $1-20$. https://doi.org/10.1080/13603116.2 017.1412510

Maggio, D., Shogren, K. A., Wehmeyer, M. L., \& Nota, L. (2019). Self-determination and future goals in a sample of adults with intellectual disability. Joumal of Intellectual Disability Research, 1-11. https://doi.org/10.1111/jir.12696

Marlina, L. (2015). Model rational emotive behavior therapy untuk meningkatkan kepercayaan diri disabilitas netra "Ra." Pekerjaan Sosial, 14(1).

Miles, M. B., Huberman, A. M., \& Saldana, J. (2014). Qualitative data analysis: A methods sourcebook. Thousand Oaks, California 91320: SAGE Publications, Inc.

Muchtar, U. A. (2018). Pendidikan Agama Islam bagi anak berkebutuban kbusus (abk) di Sd Terpadu Putra Harapan Purwokerto. IAIN purwokerto.

Pennycook, A. (2017). The cultural politics of Englishas an international language. New York: Routledge.

Pittard, E. (2015). Who does critical pedagogy think you are? Investigating how teachers are produced in critical pedagogy scholarship to inform teacher education. Pedagogies: $A n$ International Journal, 1-21. https://doi.org/10.1080/1554480X. 2015.1066679

Rahmawati, A. (2018). Konsep pembelajaran PAI bagi anak berkebutuhan khusus di sekolah inklusi: Studi kasus di SD Semai Jepara. Edukasia Islamika.

Ratner, H. (2016). Modern settlements in special needs education: Segregated versus inclusive education. Science as Culture, 1-21. https://doi.org/10.1080/09505431.2 015.1120283

Retnaningsih, D., \& Dini, I. K. (2016). Analisa dukungan keluarga dengan beban orangtua dalam merawat anak penyandang cacat tingkat SD di SLB Negeri Semarang. In Seminar Nasional IPTEK Terapan (SENIT) 2016 Pengembangan Sumber Daya Lokal Berbasis IPTEK (Vol. 1).

Rillotta, F., \& Alexander, J. (2020). Roles and responsibilities of developmental educators: Disability professionals supporting Australians with disability. International Journal of Disability, Development and Education, 1-16. 
Idi Warsah / Ta'dib: Jurnal Pendidikan Islam, Vol. 9 No. 1 (2020)

ISSN 1411-8173 | E-ISSN 2528-5092

https://ejournal.unisba.ac.id/index.php/tadib/article/view/6540

https:// doi.org/10.1080/1034912X. 2020.1719987

Rusdiyanto. (2018). Implementasi pendidikan inklusi pada mata pelajaran pendidikan agama Islam. Tarlim: Jumal Pendidikan Agama Islam, 1(1).

Sabaria, S. (2019). Strategi guru PAI dalam meningkatkan kemampuan psikomotorik siswa autis di SLB Negeri Curup Rejang Lebong. Annizom, 4(1).

Schwimmer, M. (2019). Rorty, post-critical pedagogy and hope: a response. Ethics and Education, 14(4), 497-504. https://doi.org/10.1080/17449642.2 019.1669355

Sexton, E., Donovan, M. O., Mulryan, N., \& Mccallion, P. (2016). Whose quality of life? A comparison of measures of self-determination and emotional wellbeing in research with older adults with and without intellectual disability. Journal of Intellectual \& Developmental Disability, 41(4), 324 337.

https://doi.org/10.3109/13668250.2 016.1213377

Sukijan, S. (2018). Pendidikan agama islam bagi anak tunagrahita di sekolah luar biasa yayasan pembinaan anak cacat Semarang. At-Tajdid: Jurnal Pendidikan Dan Pemikiran Islam, 1(2).

Supandi. (2018). Problematika guru dalam memberikan penguatan (reinforcement) mata pelajaran PAI di MTs Al-Anwar Sanah Tengah Waru Pamekasan. Al-Ulum: Jurnal Penelitian Dan Pemikiran Ke Islaman, 5(2), 23-32.

Susiana. (2017). Problematika pembelajaran PAI di SMKN 1 Turen. Jurnal Pendidikan Agama Islam Al-Thariqah, 2(1), 73-88.

Ware, H., \& Schuelka, M. J. (2019). Constructing 'disability' in Myanmar: teachers, community stakeholders, and the complexity of disability models. Disability \& Society, 1-22. https://doi.org/10.1080/09687599.2 019.1580186

Warsah, I. (2020a). Forgiveness Viewed from Positive Psychology and Islam. Islamic Guidance and Counseling Journal, 3(2), 2614-1566. https://doi.org/10.25217/igcj.v3i2.8 78

Warsah, I. (2020b). Islamic psychological analysis regarding to rahmah based education portrait at IAIN curup. Psikis : Jurnal Psikologi Islami, 6(1), 2941.

Warsah, I., Aisa, O., \& Sendi, M. (2020). Strategi Implementatif KKNI Pendidikan Islam di IAIN Curup dalam Pembelajaran. Jurnal Tarbiyatuna, 11(1), 77-90.

Warsah, I., \& Uyun, M. (2019). Kepribadian pendidik: telaah psikologi islami. Psikis: Jurnal Psikologi Islami, 5(1), 6273.

Yuliana, Y. (2019). Diskriminasi Terhadap Penyandang Disabilitas Pengguna Jasa Angkutan Udara. (Studi Putusan Mahkamah Agung Nomor 439 PK/Pdt/2017). Nusantara: Jurnal Ilmu Pengetabuan Sosial, 6(3), 536-547. https://doi.org/10.31604/jips.v6i3.2 019.536-547

Zubaidillah, M. H., \& Nuruddaroini, M. A. S. (2019). Analisis Karakteristik Materi Pelajaran Pendidikan Agama Islam di Jenjang SD, SMP dan SMA. Addabana: Jumal Pendidikan Agama Islam, 2(1), 1-11. 